\title{
METABOLIC POTENTIAL OF BACTERIA STRAINS ISOLATED FROM POULTRY INDUSTRY WASTE
}

\section{POTENCJAŁ METABOLICZNY SZCZEPÓW BAKTERYJNYCH POZYSKANYCH Z ODPADÓW PRZEMYSŁU DROBIARSKIEGO}

Department of Chemistry, Microbiology and Environmental Biotechnology, West Pomeranian

University of Technology, Szczecin, Poland

\begin{abstract}
Streszczenie. Skład mikrobiologiczny odpadów przemysłu drobiarskiego jest bardzo zróżnicowany. Zasiedlają je drobnoustroje, które do swojego wzrostu wykorzystują zawarte w nich substancje organiczne. Duże znaczenie w szybkości rozkładu materii organicznej ma odpowiedni skład mikroorganizmów. W związku z tym bardzo pożądane są drobnoustroje, które jednocześnie działają na rozkład kilku związków. W badaniu określono aktywność metaboliczną szczepów bakteryjnych względem lipidów, białka oraz skrobi. Szczepy zostały wyizolowane ze środowiska odpadów podrobiarskich. Potencjał metaboliczny szczepów bakteryjnych określono na podstawie indeksu aktywności, uwzględniając średnicę strefy hydrolizy i średnicę kolonii. Szczepy bakteryjne w różnym stopniu rozkładały związki organiczne. Ich aktywność metaboliczna oraz ukierunkowanie na substraty były zależne od rodzaju wyizolowanych szczepów bakteryjnych.
\end{abstract}

Key words: enzymatic activity, bacteria, organic compounds, poultry waste.

Słowa kluczowe: aktywność enzymatyczna, bakterie, związki organiczne, odpady drobiarskie.

\section{INTRODUCTION}

The poultry industry waste contain a spectrum of chemicals, from the simple to complex ones like fats, proteins, including keratin, and sugars that are the source of carbon and energy for inhabiting microorganisms. Having specific hydrolytic abilities by some microorganisms can help the decomposition and management of above compounds and in consequence contribute to produce more valuable components. One of such examples are keratinolytic microorganisms, that due to their capabilities to produce keratinase, are applied to improve the nutritional value of feathers used as feed additive (Syed et al. 2009; Brandelli et al. 2015; Kazzaz et al. 2015). Enzymatic activity of microorganisms inhabiting different environments may vary within broad range (Carrim et al. 2006; Lechuga et al. 2016).

There are strains that are specialized in degradation of many compounds. The example are bacteria from Bacillus sp. genus (Hasan et al. 2006; De Oliveira et al. 2017). Strains with such properties can be applied to biodegrade organic waste materials from poultry industry, that

Corresponding author - Adres do korespondencji: llona Wrońska, Department of Chemistry, Microbiology and Environmental Biotechnology, West Pomeranian University of Technology, Szczecin, Juliusza Słowackiego 17, 71-434 Szczecin, Poland, e-mail: ilona.wronska@zut.edu.pl 
after appropriate processing, can be used as a substrate for methane fermentation in a biogas-producing facility (Patinvoh i in. 2016).

The aim of the study was to evaluate the metabolic potential of bacterial strains towards fat, protein, and starch isolated from poultry waste environment.

\section{MATERIAL AND METHODS}

Bacterial strains with various metabolic potentials were isolated from the environment of poultry waste, from which the following were selected to tests: feathers (chicken, duck, turkey, and goose), slime from liquid waste reservoir, biological sludge, and compost proper. The material for tests was collected from poultry processing plant in Western Poland on various dates in 2015-2016. Microorganisms were cultured on solid substrates including fat (Kosewska 1991), protein (Kędzia and Koniar 1980), and starch (Cooney and Emerson 1964) as the only carbon source. Bacterial cultures were incubated at $25^{\circ} \mathrm{C}$ for $3-5$ days. Bacterial strains were subject to assessment of activity index taking into account the diameter of hydrolysis zone to colony diameter. Among bacterial strains with the highest activity, 12 distinguishing ones were selected and their metabolic potential for protein and fat was determined. Fragment of bacterial $16 \mathrm{~S}$ rDNA of selected strains was amplified by means of MicroSeq method, and then sequenced and compared to database of DNA fragments.

Applying Statistica 12 software, Duncan test was carried out to determine the uniform groups of tested bacterial strains against different activities.

\section{RESULTS AND DISCUSSION}

Selected poultry industry waste types were numerously inhabited by microorganisms, among which 100 bacterial strains with different metabolic activities were isolated (Table 1). They were, among others: Aeromonas veronii, Bacillus licheniformis, Bacillus megaterium, Brevibacterium luteolum, Cellulosimirobium cellulans, Micrococcus luteus. Salminen and Rintala (2002) reported that poultry waste is a convenient environment for microorganisms, due to which is inhabited by many microbial species, also such ones that can be a potential threat.

Fat-decomposing bacteria were dominant group of isolated microorganisms. Gurung et al. (2013) and Veerapagu et al. (2013) reported that Bacillus and Pseudomonas genera are bacteria that produce lipase. The largest population of lipolytic bacteria was isolated from feathers (42), smaller from biological sludge (9), while the smallest from compost proper (7) and slime (6). The lipolytic activity index for bacterial strains ranged from 1.1 to 3.5.

Another group of isolated bacteria consisted of bacteria bale to decompose protein (Fig. 1). Their largest population was isolated from feathers (15), smaller from slime (4), then from biological sludge (4), and compost (2). The proteolytic activity index of bacterial strains ranged from 1.1 to 4.2 .

Amylolytic bacteria appeared to be the smallest group. Their highest number was isolated from biological sludge (5), lower from feathers (3), and compost (3). The activity index ranged from 1.1 to 2.8 . 
Table 1. Number of bacterial strains showing metabolic activity

Tabela 1. Liczebność szczepów bakteryjnych wykazujących aktywność metaboliczną

\begin{tabular}{lccc}
\hline $\begin{array}{c}\text { Activity index } \\
\text { Indeks aktywności }\end{array}$ & \multicolumn{3}{c}{$\begin{array}{c}\text { Enzymatic activity } \\
\text { Aktywność enzymatyczna }\end{array}$} \\
\cline { 2 - 4 } & $\begin{array}{c}\text { lipolytic } \\
\text { lipolityczna }\end{array}$ & $\begin{array}{c}\text { proteolytic } \\
\text { proteolityczna }\end{array}$ & $\begin{array}{c}\text { amylolytic } \\
\text { amylolityczna }\end{array}$ \\
\hline $1.5>\mid A>1$ & 29 & 4 & 7 \\
\hline $3>\mid A>1.5$ & 33 & 20 & 4 \\
\hline $\mid A>3$ & 2 & 1 & 0 \\
\hline
\end{tabular}
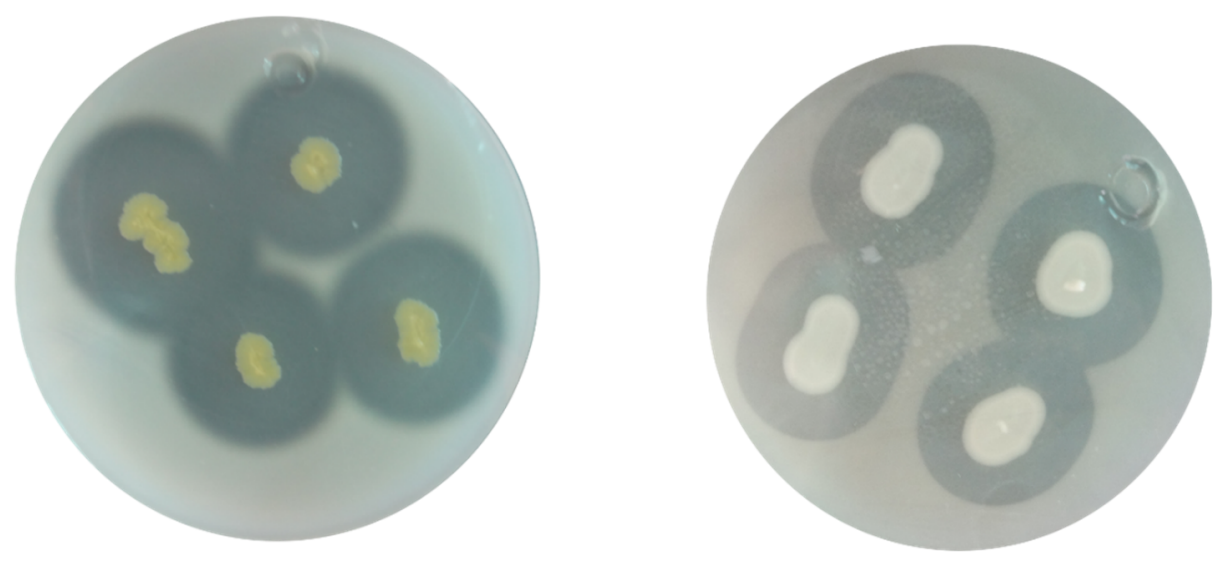

Fig. 1. Examples of isolated bacterial strains with proteolytic ability

Ryc. 1. Przykłady wyizolowanych szczepów bakterii o zdolnościach proteolitycznych

Selected 12 bacterial strains showed different hydrolytic activity at the same time towards fat and protein. It was found that bacterial strains better metabolized protein than fat as evidenced by achieved values of activity index (Fig. 2, 3).

The highest fat degradation activity was recorded for strains No. 1, 6, 7, 8, that significantly differed from other tested ones. Their average activity amounted to IA $=1.5$ (Fig. 2).

In the case of protein metabolizing, the highest activity $I A=4.2$ was observed for strain No. 6 (Fig. 3). Other strains that were characterized by high protein-hydrolyzing activity were strains No. 2 and 11. Five strains were characterized by lower proteolytic activity as compared to other ones, and their activity index was about 1.5.

Twelve isolated bacterial strains are distinguished by ability to simultaneous degradation of protein and fat and diverse enzymatic degree. Metabolic potential of bacteria towards simultaneous enzymatic decomposition of various organic substances, including protein, starch, and fat, as well as more complex compounds, is also confirmed by other authors (Przybulewska et al. 2006). Tendency of metabolic capabilities of bacteria towards decomposing substances with different structures and properties are dependent on the strain and organic compound tested. Tarntip and Sirichom (2011) found that inoculum composed of several bacterial strains characterized by high activity to organic compounds, are an effective solution to reduce the nuisance of wastewater from poultry industry. Lipolytic bacteria are extremely important for managing the sediments due to the surface decomposition of triglyceride layer that make impossible to penetrate the oxygen to the surface of the sewage (Facchin et al. 2013). 
Lipolytic activity Aktywność lipolityczna

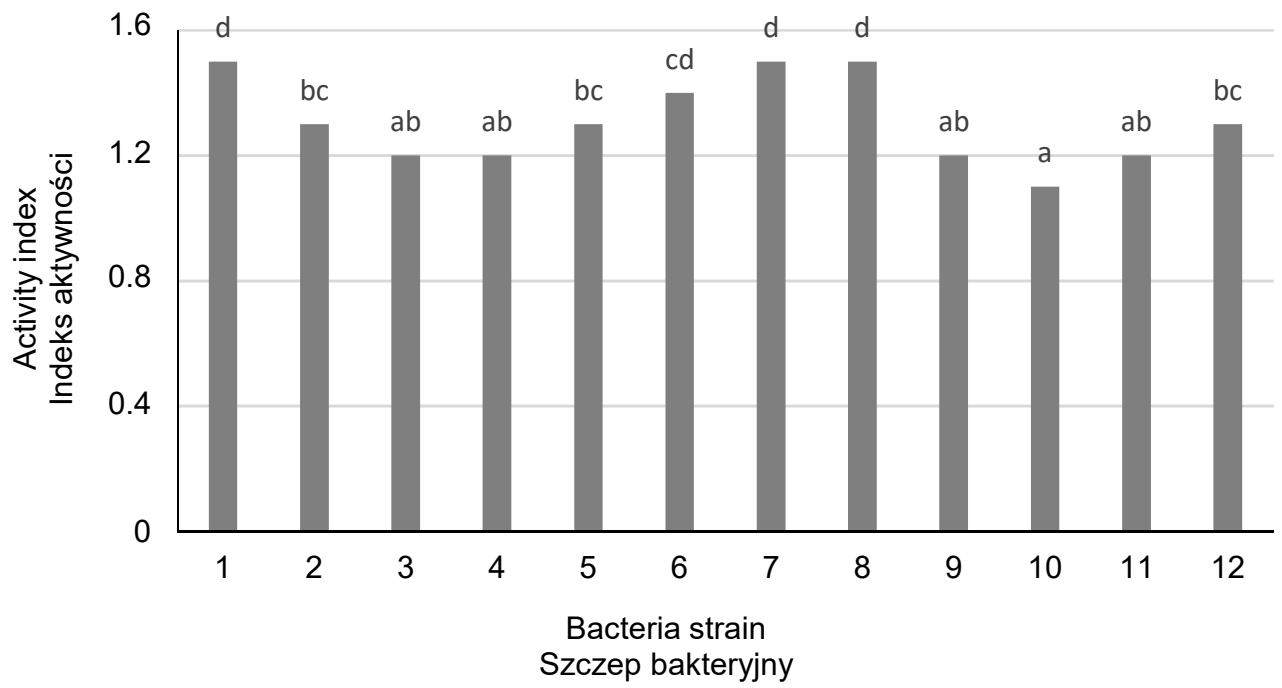

Fig. 2. Lipolytic activity of selected bacterial strains

Ryc. 2. Aktywność lipolityczna wybranych szczepów bakteryjnych

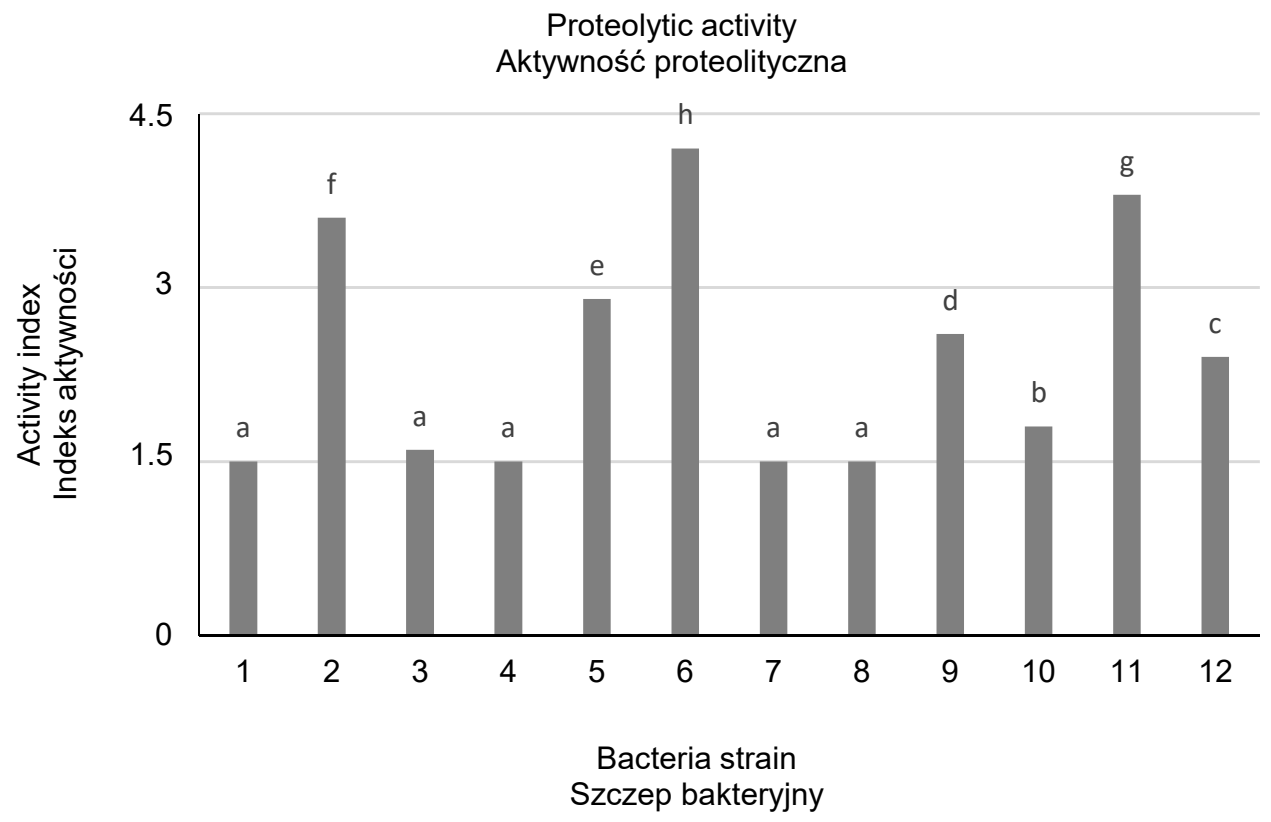

Fig. 3. Proteolytic activity of selected bacterial strains

Ryc. 3. Aktywność proteolityczna wybranych szczepów bakteryjnych

\section{CONCLUSIONS}

1. Bacterial strains isolated from the poultry waste metabolized organic compounds contained to a different degree. Examples of strains the presence of which was found in tested materials were: Aeromonas veronii, Bacillus licheniformis, Bacillus megaterium, Brevibacterium luteolum, Cellulosimirobium cellulans, Micrococcus luteus. 
2. Level of degradation activity towards complex compounds depended on the type of isolated bacterial strains. In the case of protein decomposition, the IA was from 1.1 to 4.2 , while activity index of fat degradation ranged from 1.1 to 3.5 .

3. Isolated bacterial strains originating from the poultry industry waste much better hydrolyzed protein rather than lipid substances.

\section{REFERENCES}

Brandelli A., Sala L., Kalil S.J. 2015. Microbial enzymes for bioconversion of poultry waste into addedvalue products. Food. Res. Int. 73, 3-12. DOI: 10.1016/j.foodres.2015.01.015.

Carrim A.J.I., Barbosa E.C., Vieira J.D.G. 2006. enzymatic activity of endophytic bacterial isolates of Jacaranda decurrens Cham. (Carobinha-do-campo). Braz. Arch. Biol. Techn. 49(3), 353-359. DOI: 10.1590/S1516-89132006000400001.

Cooney D.G., Emerson R. 1964. Thermophilic fungi. An account of their biology, activities and classification. San Francisco, W.H. Freeman and Company, 188.

De Oliveira C.T., Pereira J.Q., Brandelli A., Daroit D.J. 2017. Prospecting soil bacteria from subtropical Brazil for hydrolases production. Biologia 72(2), 130-139. DOI:10.1515/biolog-2017-0025.

Facchin S., Alves P.D., Siqueira F., Barroca T., Júnia M., Kalapothakis E. 2013. Biodiversity and secretion of enzymes with potential utility in wastewater treatment. OJE 3(1), 34-47. DOI:10.4236/ loje.2013.31005.

Gurung N., Ray S., Bose S., Rai V. 2013. A broader view: Microbial enzymes and their relevance in industries, medicine, and beyond. Biomed. Res. Int. 1-18. DOI: 10.1155/2013/329121.

Hasan F., Shah A.A., Hameed A. 2006. Industrial applications of microbial lipases. Enzyme Microb. Tech. 39(2), 235-251. DOI:10.1016/j.enzmictec.2005.10.016.

Kazzaz A.E., Feizi Z.H., Guvenmez H.K. 2015. keratinolytic protease production and characterization from Bacillus sp. Isolated from Poultry Wastes. IJABPT 6(4), 63-73, http://imsear.hellis.org/handle/ /123456789/169100, access: 04.05.2017.

Kędzia W., Koniar H. 1980. Diagnostyka mikrobiologiczna. Warszawa, PZWL, 245. [in Polish]

Kosewska L. 1991. Analiza mikrobiologiczna w przemyśle spożywczym. Warszawa, WSiP. [in Polish]

Lechuga E.G.O., Zapata I.Q., Niño K.A. 2016. Detection of extracellular enzymatic activity in microorganisms isolated from waste vegetable oil contaminated soil using plate methodologies. Afr. J. Biotechnol. 15(11), 408-416. DOI:10.5897/AJB2015.14991.

Patinvoh R.J., Feuk-Lagerstedt E., Lundin M., Sárvári Horváth I., Taherzadeh M.J. 2016. Biological pretreatment of chicken feather and biogas production from total broth. Appl. Biochem. Biotechnol. 180(7), 1401-1415. DOI 10.1007/s12010-016-2175-8.

Przybulewska K., Nowak A., Mientka A. 2006. Aktywność metaboliczna bakterii degradujących styren względem rozkładu cukrów, tłuszczów i białek [Metabolic activity of styrene-degrading bacteria towards sugars, fats and proteins decomposition]. Zesz. Nauk. UP Wroc. 546, 295-302. [in Polish]

Salminen E., Rintala J. 2002. Anaerobic digestion of organic solid poultry slaughterhouse waste. A review. Biores. Technol. 83(1), 13-26. DOI:10.1016/S0960-8524(01)00199-7.

Syed D.G., Lee J.C., Li W.J., Kim C.J., Agasar D. 2009. Production, characterization and application of keratinase from Streptomyces gulbargensis. Biores. Technol. 100, 1868-1871. DOI:10.1016\%2 Fj.biortech.2008.09.047.

Tarntip R., Sirichom T. 2011. Isolation of proteolytic, lipolytic, and bioemulsifying bacteria for improvement of the aerobic treatment of poultry processing wastewater. Afr. J. Microbiol. Res. 5(30), 5493-5497. DOI:10.5897/AJMR11.824.

Veerapagu M., Sankara Narayanan A., Ponmurugan K., Jeya K.R. 2013. Screening selection identification production and optimization of bacterial lipase from oil spilled soil. Asian J. Pharm. Clin. Res. 6(3), 62-67, http://www.ajpcr.com/Vol6Suppl3/155.pdf, access: 08.05.2017. 
Abstract. Microbial composition of poultry industry wastes was very diverse. They are inhabited by microorganisms that use organic substance to their growth. An appropriate composition of microorganisms is very important in the organic matter decomposition rate. Therefore, microorganisms that contribute to decomposition of several compounds are quite desired. The study dealt with the evaluation of metabolic activity of bacterial strains towards lipids, protein, and starch. The strains were isolated from the poultry waste environment. Metabolic potential of bacterial strains was determined based on the activity index and taking into account the hydrolysis zone diameter and colony diameter. Bacterial strains to a different degree decomposed the organic compounds. Their metabolic activity and direction towards substrates depended on the type of isolated bacterial strains. 